\title{
MULTIS VOCIBUS DE LINGUA ANGLICA: TOWARDS AN OUTLINE OF AN EMOTIONAL PROFILE OF ENGLISH AS A MAJOR GLOBALIZING NATURAL LANGUAGE OF TODAY
}

\author{
STANISEAW PUPPEL
}

\section{Introduction}

With the English language being around as a major globalizing language for quite some time now (see Crystal 1997), it has become timely to make an attempt at outlining an 'emotional profile' of that language. When a particular phenomenon, be it a tangible piece of handicraft (e.g. a tool) or an intangible cultural phenomenon (e.g. an intellectual trend, a book, etc.), is present in the 'social landscape' (or as one might say, in the 'maximally open and thus maximally accessible public space') and when many (if not all) individuals have finally got used to its prolonged presence, emotional profiles of such a phenomenon usually emerge among those who are aware of its prolonged and socially protruded existence. The case with the prolonged presence of English as a socially, culturally and communicationally privileged phenomenon in the space of the natural language global arena (hence NaLGA), is a very clear instance of a phenomenon whose emotional profile may be attempted.

Many individuals around the world have not only noticed its presence, have learned it and have come to terms with it, have clung to it in their individual careers, but have also worked out its individual and collective emotional profiles. As a consequence, a great upsurge of both more or less unconditional social appraisal for English as well as a host of more or less socially negative atti- 
tudes towards the English language have occurred in the NaLGA. This may have happened very much in accordance with the somatic marker hypothesis put forth by Antonio Damasio and his school (see e.g. Damasio 1991; Damasio 1994; Damasio 1996; Damasio 2000, and Damasio et al. 1991). According to this approach, two dichotomously organized somatic markers, namely that of 'appetitive behaviours', generally responsible for the positive feelings of appreciation and need, and 'avertive behaviours', generally responsible for the negative feelings of aversion and rejection, would be responsible for the occurrence of these two types of emotional reactions to a prolonged presence of English as a phenomenon/state/event/process among the individual human communicating agents representing all the natural languages occurring in the NaLGA.

It is assumed here that the prolonged presence of English as a major globalizing natural language since the end of WWII, with it having 'won', at least at the present moment, the language contest on a global scale, has met with socially marked and scalable emotional reactions. They can be placed on the opposing poles of love and appreciation (as part of 'Anglophilia') on the one hand, resentment and caution (as part of 'Anglophobia'), on the other. One may thus distinguish between the establishment of the following two emotional profiles of English as polar opposites: the 'praising profile', and the 'resentment/caution profile', as demonstrated by different individuals and institutions in their different demonstrations of language awareness concerning both their native languages and English as a major target language. These two types of profiles will be briefly presented below.

\section{The 'praising profile' of English}

The praising profile of a natural language is the one which most naturally accompanies every natural language in its historical dimension, that is, through the process of its intergenerational transmission. The praising profile is based on the key concept of 'beloved language'. Fishman (1996: 20) has defined this crucial concept in the following way:

The beloved language represents the moral order. It functions similarly to that order in ennobling human life and, in addition, it is co-constituative of that order. It is not just the conventional norm; it is not just the natural and ubiquitous tool of comfortable communication with one's 'own kind'. It is also, for some, the heart of morality itself, morality that one can hear and see and feel, even as one brings it forth from one's self'.

The above definition, which, while conveniently referring to any native language occurring in the NaLGA, may also serve as an ideal reference point for all natural languages which may be placed on the somatic marker scale proposed 
above. In the case of the bilingual practice of combining the native language with any other natural language, that is, in the 'native language-target language' tandem, it is usually the native language which enjoys the status of a beloved language (expressed by the phrase "I love my native language"), while the target language may (and usually does) assume the status of a language which may be given the following emotional tags and which may, in turn, form a network organized around the concept of 'beloved language': acceptable, all right, tolerable, decent, respectable, admissible, positive, trendy, desirable, useful, pleasant, admirable and even delightful and enthusiastic.

In fact, foreign language pedagogy has not only been concerned with an overall aim of attaining success in target language acquisition by foreign/second language learners in terms of the establishment of their overall culturallinguistic-communicative competencies, but has also been - though somewhat clandestinely as a side effect - concerned with establishing in them as positive a 'tinting' of the target language as possible (see e.g. Shipley 1982). All these measures seem to follow suit in matching (or rather eclipsing) the primary 'beloved language' profile of the native language. In other words, the aim of foreign language pedagogy has been not only set at encouraging the foreign language learner to earn/attain useful and life-supporting linguistic-communicative competence in a given target language, but also at doing so with a possibly highest degree of approval towards that language. This may, in fact, be thought of as leading to a commencement of a 'language war' which may be staged and waged in the NaLGA more or less subconsciously by the parties involved (see e.g. Hutchings 2011; Shell 2001), that is, between the native and target language populations. The final result may be the native language going through a mentally-based 'belittling effect', or, simply, the diminution of the status of the native language in confrontation with the excessively promoted and prioritized target language, that is, English, inflicted by the very native communicators. A good example of a highly praising judgment of English combined with a clearly negative valuation of the native language (in this case, German) is demonstrated below (Jacob Grimm's words cited in Allibone1880).

\footnotetext{
The English language has a veritable power of expression such as, perhaps, never stood at the command of any other language of men. Its highly spiritual genius and wonderfully happy development and condition have been the result of a surprisingly intimate union of the two noblest languages in modern Europe, the Teutonic and the Romaic. It is well known in what relation these two stand to one another in the English tongue; the former supplying, in far larger proportion, the material groundwork; the latter, the spiritual conceptions. In truth, the English language, which by no mere accident has produced and upborne the greatest and most predominant poet of modern times, as distinguished from the ancient classical poetry (I can, of course, only mean Shakspeare), may, with all right, be called a world-language, and, like the English people, appears destined hereafter to prevail, with a sway more extensive even
} 
than its present, over all the portions of the globe. For in wealth, good sense, and closeness of structure no other of the languages at this day spoken deserves to be compared with it, - not even our German, which is torn, even as we are torn, and must first rid itself of many defects before it can enter boldly into the lists as a competitor with the English.

One should observe at this point that with English functioning as a lingua franca (or rather lingua globalis) of today in particular, there has been a growing concern on the part of the constantly expanding international lobby and population of foreign language educators, who by their sheer and growing numbers form what may be referred to as a stream of 'external linguopressure' (see e.g. Puppel 2007), to work out a more or less integrated and aggressive ideological stance concerning the introduction to the open public space of a more or less well-defined and more or less permanent justification for the global presence of English (see e.g. Donaldson 1984; González and Melis 2001). One may regards this framework as representing the so-called English-only (Anglophone) movement. The movement has basically recognized that English has thus far enjoyed so much international acceptance and popularity given the fact that as a heavy language (i.e. with a huge linguomass expressed by the very number of native communicators), it has been perceived as being more user-friendly and useful on an international basis than would be the case with any smaller language (see e.g. Calvet 1998; Puppel and Puppel 2005; McWhorter 2011).

Moreover, the stunning, collectively laborious and indeed very successful attempts on the part of the huge international body of English language teachers aiming at maximally magnifying the significance of English services and thus encouraging the growing cult of English world-wide have resulted in supplying to the specialized international audiences and to the open public space in general a rather exhaustive list of advantages (or 'rewards/profits') connected with English language learning and teaching and, generally, with the communicators residing in two languages, their native language and English. The list comprises advantages in the following areas: individual autonomy, individual and institutional business opportunities, individual careers, individual cognitive enrichment, communication practices, individual creativity, critical thinking, transcultural dimension, individual practice of language diversity, employability, equality, globalization, group inclusion and cohesion, transcultural/translinguistic competence, individual knowledge, language awareness, professional communication, access to varied learning strategies, mobility, social promotion, translingualism, personal satisfaction, professional qualifications, better prospects for residence abroad, access to cutting edge technology, and generally better work experience.

However, the above list also brings to the fore, may be quite unintentionally, the fact that, overall, the international body of English language teachers, mostly 
of non-English descent, is paradoxically vividly involved in such a massive and aggressive promotion of English. At the same time, very often if not all the time during their teaching careers, they may quite strongly present themselves as a huge international force acting more or less consciously against their own native languages and cultures in countless acts of English language favouritism. This is often times a manifestation of external (target language) linguopressure in its most pragmatic guise, that is, in relation to a given nation's economy put in a competitive international framework, for which the presence of English as a major globalizing language of international commerce appears pivotal. Such a concern is distinctly expressed in the following passage:

There is growing concern about the level of English proficiency at the workplace which if left unchecked could lead to the country losing its competitiveness especially in the industry and technical fields. Malaysia needs communicative competence to maintain its competitive edge in all aspects of our economic environment be it administration, education, trade or finance

(see Robinson and Zaitun 2006: 4).

The above list of Anglophile attitudes is indeed not only quite exhaustive but it is also very impressive and does reflect the praising profile of Shakespeare's language extremely well. Moreover, if applied rigorously and massively to the international groups of those individuals who have decided to learn and use English the world wide, it may undoubtedly lead (and indeed has led) to the establishment and dissemination of a very stable framework of positive feelings of both strong appreciation of and need for English as a widely (i.e. globally) and easily accessible/diffusable resource of international linguistic communication, very much in accordance with the appetitive bahaviour suggested by Damasio and his co-workers in their somatic marker hypothesis outlined above.

\section{The 'resentment/caution profile' of English}

The extremely positive profile of the English language demonstrated above is, however, not the only profile one may attest among all the 'residents' of the NaLGA of today. Much as the dichotomous framework would be expected to allow, there has also developed a negative profile of the language, namely what one may call a 'resentment/caution profile' of English as a major globalizing language of the world. This profile is connected with the fact that English has also for quite some time been very clearly viewed as a language of: international hegemony/domination/linguistic oppression/linguistic imperialism/linguistic despotism (see e.g. Phillipson 1992; 2008) in so many significant dimensions of public and private life. As such, it has been receiving severe criticism from many 
individual language preservation activists and institutions the world round, most clearly connected with the central problem of sustainability of natural language diversity, ranging from quite robust and well to do (i.e. heavy/robust) languages to those whose mere existence in the NaLGA may be described as the state of endangerment (see e.g. Tanner 2004). All this has amounted to undertaking all kinds of more or less organized attempts aimed at keeping English in check so that it should not be allowed to invade other native cultures and languages too radically and too painfully for the invaded culture-language complexes and also in order to keep other languages alive in the multilingual/plurilingual space of the NaLGA, necessarily through the application of a variety of well-prepared natural language preservation measures (see e.g. Puppel 2011).

The resentment/caution profile mandatorily involves a listing of negative attitudes towards the English language viewed as a very clear and efficient means of deethnicization and denationalization of the populations of communicators residing natively in various local cultures being subject to a more or less massive and forced entrance of English into other cultural-linguistic communities, and also as a means of quelling cultural-linguistic diversity. Thus, the profile comprises the following views on the negative status of English as a major globalizing language of today:

1. It is a language of political, economic and cultural hegemony and imperial domination bound to subjugate (or 'look down at') other weaker (lesser) natural languages and local cultures. In this respect, English may be viewed as a generally 'malignant' language.

2. It is a language whose presence vis-à-vis other natural languages in the NaLGA may lead to the development of various detrimental phenomena in relation to the other languages remaining in prolonged contact with English, for example, to their dwindling and even death in what may be called 'forced assimilation' to the invaders' culture-language complex (see e.g. Bonvillain 2004). Thus, it may be viewed as a perpetrator of linguicide through various cultural-linguistic importations, or at least responsible for pushing a weaker language into a reduced (or degraded) dimension resource-wise, or even pushing it to a dormant phase in which the native users of a language would stop being voluntarily involved in the transmission of the language to future generations (as has, for example, been the case with Irish, Ó Néill 2005; Hickey 2011; see also Thornton 1986, 1987).

3. It is a language whose presence vis-à-vis other languages in the NaLGA may deprive the users of these languages of their identity and thus weaken their sense of membership (belongingness/embeddedness) in a given local culture (or simply 'uproot' them culturally and linguistically while at the same time superficially 'installing' them in the target English culturelanguage milieu). 
4. If allowed to co-occur in a given local community together with the native language for too long, it may become an extremely difficult alien element to be curbed in its frequently negative/destructive influence on the local culture in the sense that it may be difficult to win that culture back (i.e. restoring/revitalizing it properly) to the native communicators, especially the young ones, without careful and conscious efforts on the part of local culture-language preservationists.

5. Its negative influence on local cultural-linguistic identity should, therefore, be countenanced by careful and well-planned measures introduced by local cultural-linguistic preservation/revitalization institutions and activists, based on thorough and solid research (as shown in, e.g., a welldocumented study by West and Graham 2011) so that it is saved for the future generations.

The importance of the restoration/revitalization activities as a clear manifestation of resentment/caution towards the English language may be illustrated by the following two passages which refer to a growing awareness of the importance of native North American languages and dialects (Nez 2011: 146, and Native American Indian language and culture in New York 2012, respectively):

The many different American Indian languages and dialects spoken throughout the United States are evidence of the cultural diversity of American peoples. American Indians are finding new ways to 'remake' themselves. American history does not write about the atrocities of the hundreds of tribal peoples who have gone before today, where languages, cultures were a way of life, a way of knowing, and the ceremonial practices were completely eradicated. It is obvious that in the twenty-first century American Indians are exploring their ancestral background to redefine who they once were. Language has a deep connection that is spoken from one's core of existence. Therefore, the belief and discourse of the Native elders is to hold the language and believe that the seventh generation will awaken to re-embrace the language. Every tribe has its distinctive language and culture. It was during the Indian Wars that the US Cavalry rounded up the Natives, successfully homogenized them into Indian Country, and bordered them into boarding schools to take away their spirit.

Language encompasses and expresses a worldview shaped by centuries, in some cases tens of thousands of years, of experience, knowledge, practices, spiritual beliefs, and relationships between a people, its neighbors, and its environment, which cannot be replicated in any other tongue".

By way of a brief conclusion, it should be stated that it is a universal truth that the human species, comprising all the individual communicators, does not exist outside their local cultural-linguistic complexes. Therefore, a fully human individual is the one who 'resides' more or less comfortably (i.e. is fully immersed) in one's native culture-language complex which should be properly secured against the perils of alienation and loss of native culture/language 
awareness owing to the occurrence of various external linguopressure phenomena and processes. In this context, English which has since the end of WWII 'enjoyed' the status of an invading super strong globalizing language and whose mere presence in the NaLGA has been connected with posing direct threats to other languages' cultural-linguistic heritage, their integrity, sacredness and uniqueness, has quite naturally been perceived as both a positive (appetitive) and negative (avertive) phenomenon.

The clearly negative properties of English outlined above should, therefore, be properly balanced with the clearly positive ones, as outlined above, so that the non-native English communicators' individual linguistic satisfaction connected with the voluntary acquisition of English as a target language and in the inevitable and socially desirable bilingual 'native language-English language' binding framework is properly maintained. Therefore, the humanistic goal of joining forces and creating a highly functional and socially acceptable multi/pluricultural and multi/plurilinguistic world remains the sole and urgent responsibility of the various culture-language educational institutions and dedicated individuals the world over (see e.g. Offenhäußer et al. 2010). Subsequently, the otherwise irreconcilable Anglophone and Anglophile orientations may be successfully conjoined within an ecologically sound and globally administered Pax linguisti$c a$ as the central theme of the NaLGA functioning as a metaspace for a peaceful co-existence of diverse cultures and natural languages. In it, Pax linguistica would be expressed by the major premise that every natural language, no matter how big or how small, should be valued as an asset. Moreover, in this way, communicators the world over may be smoothly placed in the more dignified multi/plurilinguistic dimension, without being forced to exercise extreme selfdefense in the form of excessive ethnocentrism, unnecessary parochialism and unwelcome xenophobia.

\section{References}

Allibone, S.A. 1880. Prose quotations from Socrates to Macaulay. Philadelphia: J.B. Lippincott and Co.

Bonvillain, N. 2004. Indians of North America: the Hopi. Philadelphia: Chelsea House Publishers. Calvet, J.L. 1987/1998. Language wars and linguistic politics. Oxford: Oxford University Press. Crystal, D. 1997. English as a global language. Cambridge: Cambridge University Press.

Damasio, A.R. 1994/2008. Descartes' error: emotion, reason and the human brain. New York: Random House.

Damasio, A.R. 1991. Somatic markers and the guidance of behaviour. Oxford: Oxford University Press.

Damasio, A.R. 1996. "Somatic marker hypothesis and the possible functions of the prefrontal cortex". Philosophical Transactions of the Royal Society of London B 351. 1413-1420. 
Damasio, A.R. 2000. The feeling of what happens: body, emotion and the making of consciousness. New York: Vintage Books.

Damasio, A.R., Tranel, A.R. and H.C. Damasio. 1991. "Somatic markers and the guidance of behavior: theory and preliminary testing". In: Levin, H.S. et al. (eds.). 217-229.

Donaldson, F. 1984. The British Council: the first fifty years. London: Cape.

Fishman, J.A. 1996. In praise of the beloved language: a comparative view of positive ethnolinguistic consciousness. Berlin: Mouton de Gruyter.

González, R.D. and I. Melis. (eds.). 2001. Language ideologies: critical perspectives on the official English movement. Vol. 2. Mahwah, N.J.: Lawrence Erlbaum Associates.

Hickey, R. 2011. The dialects of Irish: study of a changing landscape. Berlin: Mouton de Gruyter.

Hutchings, H. 2011. Language wars: a history of proper English. London: John Murray.

Kivisto, P. 2002. Multiculturalism in a global society. New York: Wiley and Sons.

Levin, H.S., Eisenberg, H.M. and A.L. Benton. (eds.). 1991. Frontal lobe function and dysfunction. Oxford: Oxford University Press.

McWhorter, J. 2011. What language is: and what it isn't and what it could be. New York: Gotham Books/Penguin Group.

Native American Indian language and culture in New York. 2012. Albany/New York: The University of the State of New York and Metropolitan Center for Urban Education.

Nez, V. 2011. "Native American language ideologies: beliefs, practices, and struggles in Indian Country". The American Indian Quarterly 35 (1). 146-147.

Offenhäußer, D., W.C. Zimmerli and M.T. Albert. (eds.). 2010. World heritage and cultural diversity. Cottbus: Brandenburg University of Technology at Cottbus.

Ó Néill, D. (ed.). 2005. Rebuilding the Celtic languages: reversing language shift in the Celtic countries. Talybont, Ceredigian: Y Lolfa Cyf.

Phillipson, R. 1992. Linguistic imperialism. Oxford: Oxford University Press.

Phillipson, R. 2008. "Lingua franca or lingua frankensteinia? English in European integration and globalization". World Englishes 27 (2). 250-267.

Puppel, S. 2007. "Interlingwalizm czy translingwalizm? Interkomunikacja czy ranskomunikacja? Uwagi w kontekście współistnienia języków naturalnych w ramach globalnej wspólnoty kulturowo-językowo-komunikacyjnej”. In: Puppel, S. (ed.). 79-94.

Puppel, S. (ed.). 2007. Ochrona języków naturalnych. Poznań: Katedra Ekokomunikacji UAM.

Puppel, S. (ed.). 2007. Spoteczeństwo-kultura-język. W stronę interakcyjnej architektury komunikacji. Poznań: Katedra Ekokomunikacji UAM.

Puppel, S. 2011. "The universal natural language preservation mechanism: an ecological approach". In: Puppel, S. (ed.). Transkomunikacja II: w strone sprofilowania przestrzeni publicznej jako wielopłaszczyznowej przestrzeni komunikacyjnej. Poznań: Katedra Ekokomunikacji UAM. 91-99.

Puppel, S. and J. Puppel. 2005. 'Zagadnienie percepcji języka naturalnego w triadzie: język ojczysty - język globalny - język sąsiedni na przykładzie triady: język polski - język angielski język niemiecki w ujęciu ekolingwistycznym: próba typologii”. Scripta Neophilologica Posnaniensia VII. 55-95.

Robinson, J.S. and A.B. Zaitun. 2006. "The utilization and integration of ICT tools in promoting English language teaching and learning: reflections from English option teachers in Kuala Langat District, Malaysia". International Journal of Education and Development Using Information and Communication Technology (IJEDICT) 2 (2). 4-14.

Said, E. 1993. Culture and imperialism. London: Chatto and Windus.

Shell, M. 2001. "Language wars". CR: The New Centennial Review 1 (2). 1-17. 
Shipley, J.T. 1982. In praise of English: the growth and use of language. New York: Random House.

Skutnabb-Kangas, T. 2002. Why should linguistic diversity be maintained and supported in Europe? Some arguments. Strasbourg: Council of Europe.

Tanner, M. 2004. The last of the Celts. Yale: Yale University Press.

The Nuffield languages inquiry. 2000. Languages: the next generation. London: The Nuffield Foundation.

Thornton, R. 1986. We shall live again: the 1870 and 1890 Ghost Dance Movement as demographic revitalization. Cambridge: Cambridge University Press.

Thornton, R. 1987. American Indian holocaust and survival: a population history since 1492. Norman: University of Oklahoma Press.

West, C. and A. Graham. 2011. Attitudes towards the Gaelic language. Edinburgh: Scottish Government Social Research.

Wilson, G.N. 2009. “'But the language has got children now': language revitalization and education planning in the Isle of Man”. Shima: The International Journal of Research into Island Cultures 3 (2). 15-31.

Wilson, J. 1999. The Earth shall weep: a history of native Americans. New York: Grove Press. 